\title{
Regulation and activation of p53 and its family members
}

\author{
MAE Lohrum ${ }^{1}$ and KH Vousden ${ }^{\star, 1}$ \\ ${ }^{1}$ ABL Basic Research Program, NCI-FCRDC, Building 560, Room 22-96, West \\ 7th Street, Frederick, Maryland, MD 21702-1202, USA \\ * Corresponding author: KH Vousden; Tel: 301846 1726; Fax: 301846 1666; \\ E-mail: vousden@ncifcrf.gov
}

Received 7.10.99; accepted 26.10.99

Edited by R Knight

\begin{abstract}
Regulation of the p53 tumor suppressor protein occurs to a large extent through control of protein stability, and the MDM2 protein has been shown to play a key role in targeting p53 for degradation. Stress signals that activate the p53 response lead to stabilization of p53 through inhibition of MDM2 mediated degradation, and it is becoming evident that a number of mechanisms exist to abrogate this activity of MDM2. Other members of the 553 protein family may also be regulated through protein stability, although MDM2 is not responsible for the degradation of $p 73$. Nevertheless, interactions of $p 63$ and p73 with MDM2 or p53 have been described, suggesting that each of the p53-related proteins can play some role in regulating the activity of the others
\end{abstract}

Keywords: p53; p73; p63; MDM2; E2F-1; protein stability

\section{Common themes, different players: Regulation of p53, p73 and p63}

The tumor suppressor protein p53 has been studied intensively over the past decade, and it is clear that p53 activity plays an important role in preventing tumor development. p53 is a potent inhibitor of cell growth and so control of p53 activity is essential during normal growth and development. Regulation of p53 has been described at the level of transcription and translation, ${ }^{1}$ and through allosteric regulation of p53 conformation. ${ }^{2}$ However, by far the most attention has been directed to modulation of p53 protein stability which appears to be one of the critical mechanism by which p53 function is regulated, and the mechanisms through which p53 is degraded have been under intense scrutiny over the past few years. The recent identification of the $p 53$ related proteins, p63 and p73, has raised the question of whether all the family members are regulated through the same mechanisms to allow for a coordinated response, or whether each protein is subject to independent regulation. This review aims to summarize the present models on how the p53 protein is degraded and how these pathways are inhibited to allow activation of a p53 response, with comparisons to our, as yet, less comprehensive understanding of how p73 and p63 activity is controlled.

\section{Key player in the regulatory cellular concert: MDM2}

The importance of regulation of p53 stability was revealed in key studies showing that DNA damage induced activation of the p53 response resulted in a rapid increase in protein level due to a significant increase in protein half-life..$^{3,4}$ Use of protease inhibitors and cells lacking components of the proteasome indicated that the principal regulator of p53 stability is the ubiquitin-dependent proteolytic machinery, ${ }^{5,6}$ although a role for calpain has also been suggested by several studies. ${ }^{7-9}$ Although elegant studies showed that a viral protein, the human papillomavirus E6 protein, could efficiently target p53 for degradation, ${ }^{10}$ a cellular factor that can regulate the rapid degradation of p53 in normal cells remained elusive until the MDM2-protein was identified as a regulator of p53 levels through proteasome-dependent degradation. ${ }^{11-13}$ MDM2 has long been known as the product of a p53 inducible gene, ${ }^{14,15}$ although there is no evidence that MDM2 mediates any of the p53-functions such as cell-cycle arrest or apoptosis. ${ }^{16,17}$ On the contrary, MDM2 has been shown to inhibit p53 functions by binding to the $\mathrm{N}$ terminus of the p53 protein and thereby blocking the normal trans-activating function of this domain. ${ }^{18-21}$ An autoregulatory feedback loop is therefore established between p53 and MDM2, where p53 activates expression of its own negative regulator. ${ }^{15}$ The importance of MDM2-regulation of the p53 protein is reflected in the fact that MDM2 deficient mice show a very early embryonic lethality which is entirely rescued when the p53 gene is simultaneously deleted. ${ }^{22,23}$ This strongly argues that a crucial function of MDM2, at least during early development, is the regulation of the growth inhibitory activities of p53. Furthermore, inhibition of MDM2 activity in normal cells also leads to elevation of p53 levels and activation of a p53 response. ${ }^{24,25}$ Taken together, it seems likely that the MDM2/p53 feedback loop maintains p53 at low levels in normally growing, unstressed cells. Perturbation of this regulatory loop results in stabilization of p53, and this situation is seen in tumor cells expressing mutant forms of p53 that have lost transcriptional activity. Mutations of this type not only abolish the tumor suppressive functions of p53 but also prevent p53 activation of MDM2. The consequence of this is the stabilization of p53, a characteristic often associated with mutant p53 in tumor cells.

Having established a role for MDM2 in the degradation of $\mathrm{p53}$, rapid progress has been made in elucidating the mechanisms by which MDM2 functions. It has been shown that MDM2 reduces the intracellular p53 levels in a ubiquitin-proteasome mediated pathway, ${ }^{11,12}$ and that 
MDM2 itself can function as an E3 ubiquitin-ligase, mediating both p53-ubiquitination as well as its own ubiquitination in vitro. ${ }^{26-28}$ E3 ligases are required for the specificity of ubiquitin conjugation, a multi-enzyme process that leads to the covalent modification of proteins with ubiquitin, ${ }^{29}$ and the ubiquitination of p53 and MDM2 itself requires only $E 1$ (ubiquitin activating enzyme) and $E 2$ (ubiquitin conjugating enzyme) in addition to MDM2. ${ }^{28}$ This activity of MDM2 depends on the RING finger in the Cterminus of the protein and in this respect MDM2 shows similarity to other RING finger containing proteins that have intrinsic capacities to mediate ubiquitination. ${ }^{30}$ It seems possible that these RING fingers, which vary substantially in their sequences, may be responsible for the target specificity of the E3 ligases. ${ }^{28,30}$

In addition to the role of MDM2 as an E3 ligase, the efficient degradation of $\mathrm{p} 53$ is also dependent on the nucleo-cytoplasmatic shuttling of MDM2. ${ }^{31-35}$ The importance of subcellular transport of MDM2 was demonstrated by using drugs that block nuclear export ${ }^{31-33}$ and MDM2mutants that are deficient for nuclear export. ${ }^{31,34}$ Although these studies are supportive of the model in which MDM2 is responsible for moving p53 from the nucleus to the cytoplasm, where degradation occurs through cytoplasmic proteasomes, it is possible that MDM2 and p53 export from the nucleus independently. A nuclear export signal has recently been described in the oligomerization domain of p53 suggesting direct regulation of p53 export and stability depending on the oligomerization state of $p 53 .{ }^{36}$ Although the details of this regulation remain to be established, overall it seems clear that p53 degradation can be regulated by control of the subcellular localization of p53 and MDM2.

Both p53 and MDM2 have been shown to bind to many other proteins, and these interactions can also influence the ability of MDM2 to target p53 for degradation. Several of these interactions result in the inhibition of degradation, and may play a role in allowing the activation of p53 (see below). By contrast, the transcriptional coactivators p300/ CBP appear to play an important role in allowing MDM2 mediated degradation of p53. p300/CBP binding to the trans-activation domain of $p 53$ is important for the transcription function of p53 and its growth arrest and apoptotic functions. ${ }^{37-40}$ Interestingly, p300 binding has been shown to be particularly important for activation of MDM2 expression ${ }^{41}$ and degradation of p53. In addition, p300 has been proposed to play a direct role in promoting degradation of p53 by interacting with both MDM2 and p53 through domains distinct from those important for p300 to serve as a transcriptional coactivator. ${ }^{42}$ In this way p300 might act as a binding platform to allow assembly of the protein complexes necessary for p53 degradation.

\section{New insights into p73-degradation}

p73, which shows highest homology to p53 within the core DNA-binding region, has been shown to trans-activate similar target genes as p53, although the relative efficiency of transcriptional activation can differ. ${ }^{43-46}$ Various isoforms of p73 stimulate the expression MDM2, ${ }^{47}$ and since most studies show that MDM2 also reduces p73-dependent transcription in different in vitro reporter assays, ${ }^{4-49}$ it would appear possible that a similar feedback loop to that seen with p53 and MDM2 can exist for p73. Inhibition of p73 function by MDM2 is dependent on the interaction between the two proteins, prompting several studies to determine whether the stability of $p 73$ is also regulated by MDM2. Like p53, the p73 alpha protein is degraded though the ubiquitindependent proteasome pathway, ${ }^{46,48}$ but it is now clear that MDM2 does not mediate degradation of $\mathrm{p} 73$ alpha or beta. ${ }^{47-}$ 49 In contrast to its effect on the p53-protein, MDM2 stabilizes p73 alpha and beta levels, ${ }^{47,50}$ suggesting that MDM2 binding may protect p73 from the normal degradative mechanisms (Figure 1). The basis for the resistance of p73 to MDM2 mediated degradation is not yet understood, although the observation that the extreme C-terminus of p53, a region not conserved in $\mathrm{p73}$, is necessary for allowing efficient degradation in response to $\mathrm{MDM} 2^{51}$ suggests a contribution of this region.

\section{Stabilization of p53 upon cellular stress signals}

In order to perform its cellular functions of growth arrest and/or apoptosis, the basal levels of p53 must be raised quickly in response to cellular stress signals such as DNA damage, oncogene activation or hypoxia. During the last years considerable insight has been gained as to how p53 can be stabilized and activated, and how the normally efficient degradation of p53 can be inhibited. Most of these studies have focused on the elucidation of how p53 can overcome MDM2-mediated degradation, and how the feedback-loop between $\mathrm{p} 53$ and MDM2 can be interrupted.

It seems clear now that the MDM2-mediated degradation of p53 can be overcome through several independent mechanisms (Figure 2). One of the most straightforward ways to stabilize p53 would be to prevent the p53/MDM2 interaction by stress signal induced modifications of p53 or MDM2 or both. Various DNA-damaging agents which stabilize p53 have been shown to induce site-specific phosphorylation of $\mathrm{p} 53^{52}$ and many kinases, including ATM, ATR, DNA-PK, JNK and CKI, can phosphorylate the N-

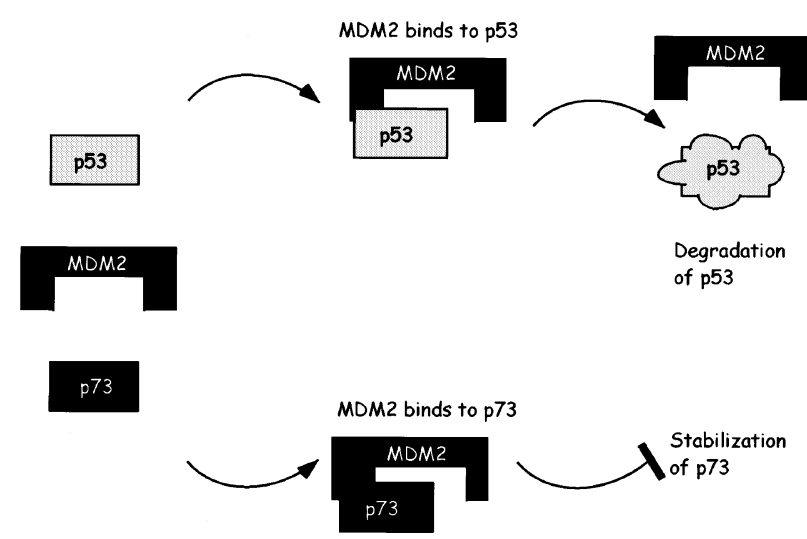

Figure 1 MDM2 binds to $p 53$ and p73, resulting in degradation of $p 53$ and stabilization of $\mathrm{p} 73$ 
terminal portion of p53 in vitro. ${ }^{53}$ Various studies have shown that phosphorylation of the p53-protein or p53peptides at serine 15 , serine 20 , serine 37 or threonine 18 reduces the interaction between $\mathrm{p} 53$ and $M D M 2^{54-57}$ and these observations are supported by the structural requirements for $\mathrm{p} 53$ and MDM2 to form a complex. ${ }^{58}$ Mutant p53 with substitutions of both serines 15 and 37 to aspartic acid, mimicking phosphorylation of those two sites, is slightly resistant to complete degradation by MDM2, ${ }^{59}$ while mutation of serine 20 to a non-phosphorylable amino acid results in enhanced sensitivity to degradation. ${ }^{55}$ The dependence on phosphorylation of any of these sites has been difficult to prove however, and mutation of all possible phosphorylation sites in this $\mathrm{N}$-terminal region of p53 does not prevent efficient stabilization in response to DNA damage. ${ }^{59,60}$ Indeed, it is becoming evident that different patterns of phosphorylations occur in response to different stress signals, suggesting that specific phosphorylation, or combinations of phosphorylation may contribute to responses to various forms of stress. In cells, ATM and the ATM-Rad3-related protein ATR have been shown to play a role in activation of p53 following DNA double-strand breaks, but other kinases are also likely to contribute to different stress responses. ${ }^{61}$ It seems most likely that phosphorylation of p53 can contribute to the stabilization of the protein in response to some activating signals, but that this modification is not essential for inhibition of MDM2 mediated degradation.

Another possible target for the above mentioned kinases is MDM2, which is also a phosphoprotein ${ }^{18,62}$ and modifications of MDM2 might inhibit its ability to target p53 for degradation. In vitro experiments have shown that MDM2 can be phosphorylated by DNA-PK and that this phosphorylation blocks its association with p53. ${ }^{63}$ MDM2 was found to be phosphorylated by casein kinase 2 in vitro, ${ }^{64}$ although so far none of these results have been confirmed in vivo.

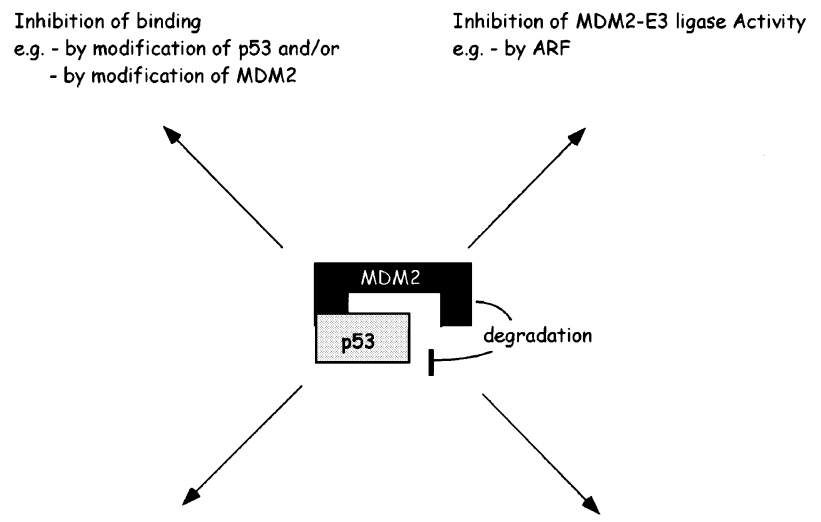

Subnuclear separation of MDM2 and $p 53$ e.g. - Nucleolar sequestration of MDM2 Downregulation of MDM2- Cytoplasmic sequestration of p53 expression

Figure 2 Inhibition of MDM2-mediated degradation of p53 occurs through multiple mechanisms

\section{p53-stabilization by ARF}

One phosphorylation-independent mechanism of p53-stabilization that has emerged during the past year involves activation of expression of the human p14ARF (mouse p19ARF) protein. The ARF protein is encoded by the INK4a-ARF locus which encodes two distinct proteins translated from alternatively spliced mRNAs: the $\alpha$-transcript comprising exons $1 \alpha, 2$ and 3 specifies p16INK4a, a cyclindependent kinase inhibitor ${ }^{65-67}$ and an alternative product, ARF ('alternative reading frame') encoded by exons $1 \beta, 2$ and 3. ${ }^{68-70}$ The importance of the ARF-INK4a locus is reflected in the fact that it shows genetic alterations in human cancers almost as often as the p53 locus ${ }^{66,67,71,72}$ and that ARFdeficient mice develop tumors. ${ }^{73}$ Furthermore, in human tumor cell lines retention of wild-type 53 often goes together with a loss of ARF expression ${ }^{74}$ suggesting that these two proteins participate in the same tumor suppressive pathway.

The first hint that ARF might function in a pathway involving p53 came from the observations that ARF can arrest cell-cycle progression and block myc/ras transformation through a p53-dependent mechanism. ${ }^{73-77}$ ARF functions by binding directly to MDM2 in a region distinct from the p53 binding domain, and prevents degradation of p53 without inhibiting the ability of p53 and MDM2 to interact. $^{74-77}$ In in vitro assays ARF can inhibit the ubiquitination function of $\mathrm{MDM} 2,{ }^{26,27}$ preventing both p53 ubiquitination as well as the auto-ubiquitination of MDM2 itself. $^{27}$ Although direct inhibition of MDM2's E3 ligase activity would efficiently prevent p53 degradation, recent studies have shown that ARF also has the ability to interfere with the nucleo-cytoplasmic shuttling of MDM2 that is essential for p53 degradation. ${ }^{31,32,34,78}$ Expression of ARF leads to the relocalization of MDM2 from the nucleoplasm into the nucleolus ${ }^{35,79}$ leaving p53 in the nucleoplasm where it is free to activate expression of the mediators of the p53. This nucleolar relocalization depends on signals in the ARF protein, and mutations of the nucleolar localization signal results in the retention of both proteins in the nucleoplasm. ${ }^{78}$

\section{Role of E2F1 in the activation of p53}

Activation of $p 53$ appears to be a general response to many types of stress, including DNA-damaging events and abnormal proliferative signals. The mechanisms underlying the response to abnormal proliferation have become evident with the realization that deregulated expression of the E2Ftranscription factors, which control the expression of many genes necessary for cell growth, can also induce both p53 and p73. Loss of the normal regulation of the E2F family is a very common event, found in most cancers, ${ }^{80}$ strongly suggesting that uncontrolled expression of these transcription factors is necessary for tumor development. A failsafe mechanism to protect from such events is revealed by the ability of one family member, E2F-1, to activate apoptosis. ${ }^{81}$ It is becoming apparent that this E2F-1 response can be carried out in a p53-dependent and a p53-independent fashion, and loss of p53 significantly diminishes the apoptotic response to deregulated E2F-1 expression (Figure 3). Deregulation of E2F-1 leads to the stabilization and activation of p53, a 
function at least partially mediated by the ability of E2F-1 to transcriptionally activate ARF expression (Figure 3). ${ }^{82}$ Interestingly, several oncogenes, including Ras, Myc, v-Abl and $E 1 A$, also lead to $p 53-$ stabilization via $A R F,{ }^{83-86}$ and it is possible that deregulation of E2F-1 in response to the activation of these mitogenic oncogenes contributes to this protective response. Therefore, the overall picture emerges that ARF seems to be a central player to protect normal cells against oncogenic stimuli, through stabilization of p53 and elimination of cells that have acquired unregulated proliferative signals. An interesting picture of how complex these interconnected regulatory activities are emerged with the observation that E2F-1, which is regulated by ubiquitindependent degradation and physically interacts with MDM2, ${ }^{87,88}$ also appears to be targeted for degradation by MDM2. ${ }^{89}$

Despite the importance of the ARF/p53 pathway in mediating the apoptotic activity of E2F-1, there is evidence that E2F-1 engages additional mechanisms to prevent aberrant growth of cells. Firstly, the ability of deregulated E2F-1 to stabilize p53 is not entirely dependent on ARF expression, and in several systems oncogenic changes that lead to loss of normal control of regulation and E2F-1 activity can stabilize p53 in ARF null cells. ${ }^{90,91}$ Secondly, E2F-1 shows strong apoptotic activities even in the absence of p53, ${ }^{92,93}$ a function that appears to reflect several activities of E2F-1. E2F-1 has recently been shown to induce apoptosis in the absence of p53 by a death receptor-dependent mechanism, in which E2F-1 sensitizes cells to apoptosis in response to $\mathrm{TNF}_{\alpha}{ }^{94}$ by inhibiting anti-apoptotic responses, including activation of $\mathrm{NF}-\kappa \mathrm{B}$ (Figure 3). A further p53 independent function of E2F-1 involves the p53 family member p73, and E2F-1 expression has recently been shown to induce transcriptional activation of $p 73$. Since $p 73$ shows apoptotic activities like $\mathrm{p} 53,{ }^{95}$ increased p73 expression in response to E2F-1 is likely to mediate at least some of the p53 independent death induced by E2F-1.

The ability of p53 family proteins to influence each other is highlighted by reports that tumor-derived p53-mutants can interfere with the functions of endogenous p73 and the ability of some isoforms of p63 to function as dominant negative inhibitiors of both $\mathrm{p} 63$ and $\mathrm{p53} .^{96,45}$ Thus, it appears that the different p53 family members might influence each other's activity as well as each other's stability.

\section{Inhibition of MDM2-mediated degradation of p53 by other mechanisms}

In addition to ARF, several other proteins have been shown to stabilize p53 by inhibition of MDM2 mediated degradation, either by binding to p53 or MDM2. c-Abl binding to p53 was shown to inhibit degradation of p53 without impinging on the interaction with $\mathrm{MDM} 2,{ }^{97}$ and stress-activated JNK has been suggested to lead to increased p53 levels by abrogating p53-interactions with MDM2. ${ }^{56}$ Binding of RB to MDM2 has also been shown to result in the inhibition of p53 degradation without preventing the p53-MDM2 interaction, ${ }^{98}$ and interestingly in this situation RB was shown to selectively induce the apoptotic response to p53, but not p53's transcriptional activity. $\beta$-catenin also protects $\mathrm{p} 53$ from ubiquitin-mediated degradation which is both MDM2-dependent and independent. $^{99}$

Regulation of sub-cellular localization is also emerging as an important mechanism to control the p53 protein stability. In a certain subset of human tumors, including neuroblastoma, p53 is sequestered in the cytoplasm and this stable p53 appears to be resistant to MDM2, probably due to a covalent modification. ${ }^{100,101}$ Also, stress induced p53 stabilization may result from cytoplasmic sequestration.

There is also evidence now that certain stress signals lead to transient decrease of MDM2-expression, which would allow p53-stabilization. Thus, inhibition of MDM2 mRNA-expression has been reported after treatment with several DNA damaging agents as well as after treatment of cells with kinase inhibitors that lead to stabilization of p53. ${ }^{61,89,102,103}$

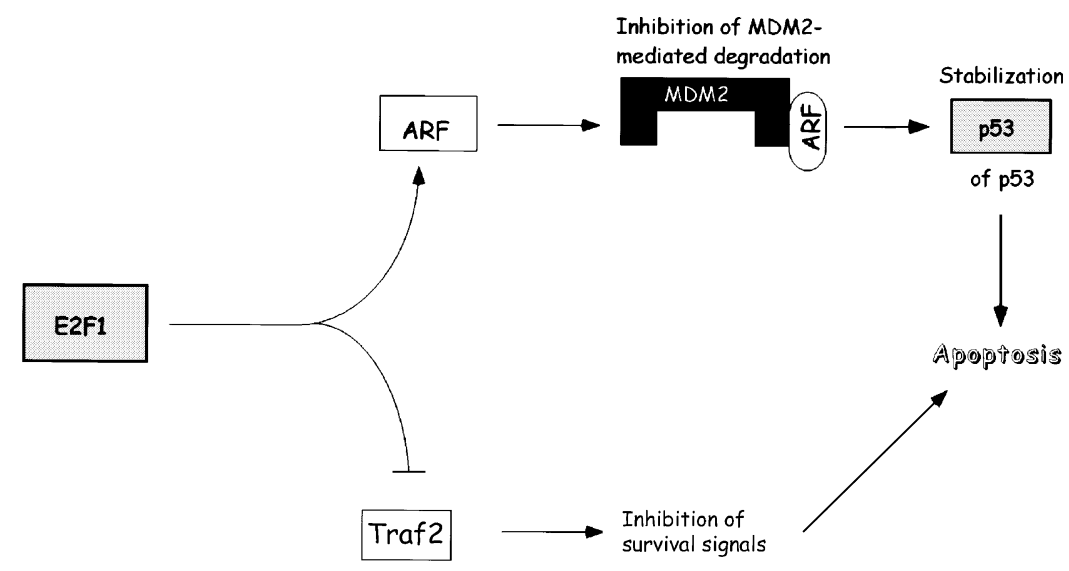

Figure 3 The E2F-1 transcription factor activates transcription of ARF leading to elevated p53 protein, and induces degradation of Traf2 and inhibition of survival signal activation 


\section{MDM2-independent regulation of p53 and p73 stability}

In addition to MDM2-regulation of p53 stability, other mechanisms to control ubiquitin dependent degradation of p53 have also been described. One of these involves the Jun(amino)-terminal kinase (JNK), which had been shown previously to mediate the ubiquitination and degradation of other target proteins like c-Jun ${ }^{104}$ and ATF2. ${ }^{105}$ JNK has also been found to form associations with p53 in nonstressed cells and it has been proposed to mediate p53 ubiquitination and degradation by forming an adaptor-molecule in the E3 ubiquitin-ligase complex. ${ }^{106}$ This JNK-mediated degradation is MDM2-independent.

Despite the similarities in their function, and the observation that, like p53, p73 protein levels are maintained by ubiquitin dependent degradation, regulation of the degradation of p53 and p73 appears to be quite distinct. This is highlighted by the response of these proteins to the oncoproteins expressed by the DNA tumor viruses, where the human papillomavirus E6 and the adenoviral proteins function to degrade p53 but not $p 73 .^{95}$ Clearly, stability regulation of p73 is not mediated by MDM2 binding in the same way as p53-degradation and the signals that activate p73 function are poorly understood. A recent step forward in this field came with the observation that p73 could be activated in response to DNA damage through a pathway involving the nonreceptor tyrosine kinase c-Abl. ${ }^{107-109}$ Cisplatin treatment lead to the c-Abl dependent stabilization of $p 73,{ }^{107}$ while gamma-irradiation resulted in tyrosine-phosphorylation of p73; ${ }^{108,109}$ both of these events led to the activation of p73. Interestingly, $\mathrm{C}-\mathrm{Abl}$ is itself phosphorylated by ATM, ${ }^{110-112}$ linking ATM to the DNA damage induced activation of both p53 and p73.

\section{Conclusion}

It is becoming apparent that the mechanisms regulating the p53-family of proteins are distinct, although some interesting parallels are beginning to emerge. Abnormal proliferation and deregulation of E2F-1 can activate both p53 and p73, albeit through different mechanisms, and c-Abl has also been shown to participate in the activation of p53 and p73 in response to DNA damage. The ability of p73 to respond to these kinds of signals is compatible with at least some role for p73 in protection from tumor progression, although the contribution of $\mathrm{p} 73$ as a tumor suppressor gene is likely to be more subtle than that seen for p53. The role for p73 and p63 during normal development ${ }^{113-115}$ suggests the possibility that signals different from those that activate p53 (which is not essential during embryogenesis) may play an important role in regulating p63 and p73 activity, and progress in this area is likely to be rapid and of great interest.

\section{Acknowledgements}

We are grateful to the members of the Vousden lab for advice and helpful criticisms of this review. This work was sponsored by the National Cancer Institute, DHHS, under contract with ABL.

\section{References}

1. FuL, Minden MD and Benchimol S (1996) Translational regulation of human p53 gene expression. EMBO J. 15: 4392-4401

2. Hupp TR and Lane DP (1994) Allosteric activation of latent p53 tetramers. Curr. Biol. 4: $865-875$

3. Maltzman Wand CzyzykL (1984) UV irradiation stimulates levels of $p 53$ cellular tumor antigen in nontransformed mouse cells. Mol. Cell. Biol. 4: 1689-1694

4. Kastan MB, Onyekwere O, Sidransky D, Vogelstein B and Craig RW (1991) Participation of p53 protein in the cellular response to DNA damage. Cancer Res. 51: 6304-6311

5. Maki CG, Huibregtse J and Howley PM (1996) In vivo ubiquitination and proteosome-mediated degradation of p53. Cancer Res. 56: 2649-2654

6. Chowdary DR, Dermody JJ, Jha KK and Ozer HL (1994) Accumulation of p53 in a mutant cell line defective in the ubiquitin pathway. Mol. Cell. Biol. 14: 19972003

7. Kubbutat MHG and Vousden KH (1997) Proteolytic cleavage of human p53 by calpain: a potential regulator of protein stability. Mol. Cell. Biol. 17: $460-468$

8. Pariat M, Carillo S, Molinari M, Salvat C, Debussche L, Bracco L, Milner J and Piechaczyk M (1997) Proteolysis by calpains: a possible contribution to degradation of p53. Mol. Cell. Biol. 17: 2806-2815

9. Zhang W, Lu Q, Xie Z-J and Mellgren RL (1997) Inhibition of the growth of WI-38 fibroblasts by benzyloxycarbonyl-Leu-Leu-Try diazomethyl ketone: evidence that cleavage of $p 53$ by a calpain-like protease is necessary for $\mathrm{G} 1$ to $\mathrm{S}$-phase transition. Oncogene 14: 255-263

10. Scheffner M, Werness BA, Huibregtse JM, Levine AJ and Howley PM (1990) The E6 oncoprotein encoded by human papillomavirus types 16 and 18 promotes the degradation of p53. Cell 63: 1129-1136

11. Kubbutat MHG, Jones SN and Vousden KH (1997) Regulation of $p 53$ stability by Mdm2. Nature 387: 299-303

12. Haupt $Y$, Maya R, Kazaz A and Oren M (1997) Mdm2 promotes the rapid degradation of p53. Nature 387: 296-299

13. Midgley CA and Lane DP (1997) p53 protein stability in tumour cells is not determined by mutation but is dependent on Mdm2 binding. Oncogene 15: $1179-1189$

14. Barak Y, Juven T, Haffner Rand Oren M (1993) Mdm-2 expression is induced by wild type p53 activity. EMBO J. 12: 461-468

15. Wu XW, Bayle JH, Olson D and Levine AJ (1993) The p53 mdm-2 autoregulatory feedback loop. Genes and Dev. 7: 1126-1132

16. Marston NJ, Crook T and Vousden KH (1994) Interaction of p53 with MDM2 is independent of $\mathrm{E} 6$ and does not mediate wild type transformation suppressor function. Oncogene 9: 2707-2716

17. Reinke $V$ and Lozano $G$ (1997) The $p 53$ targets $m d m 2$ and Fas are not required as mediators of apoptosis in vivo. Oncogene 15: 1527-1534

18. Momand J, Zambetti GP, George DL and Levine AJ (1992) The mdm-2 oncogene product forms a complex with the p53 protein and inhibits p53mediated transactivation. Cell 69: 1237-1245

19. Oliner JD, PietenpolJA, Thiagalingam S, Gyuris J, Kinzler KW and Vogelstein B (1993) Oncoprotein MDM2 conceals the activation domain of tumour suppressor p53. Nature 362: 857-860

20. Haupt $Y$, Barak $Y$ and Oren M (1996) Cell type-specific inhibition of p53mediated apoptosis by mdm2. EMBO J. 15: 1596-1606

21. Chen J, Wu X, Lin J and Levine AJ (1996) mdm-2 inhibits the G1 arrest and apoptosis functions of the p53 tumor suppressor protein. Mol. Cell. Biol. 16: $2445-2452$

22. Jones SN, Roe AE, Donehower LA and Bradley A (1995) Rescue of embyonic lethality in Mdm2-deficient mice by absence of p53. Nature 378: 206-208

23. Montes de Oca Luna R, Wagner DS and Lozano G (1995) Rescue of early embryonic lethality in mdm2-deficient mice by deletion of $p 53$. Nature 378 : 203-206

24. Böttger A, BöttgerV, Sparks A, W-LL, Howard SF and Lane DP (1997) Design of a synthetic Mdm-2 binding mini protein that activates the p53 response in vivo. Current Biology. 7: 860-869

25. Blaydes JP and Wynford-Thomas D (1998) The proliferation of normal human fibroblasts is dependent upon negative regulation of p53 function by $\mathrm{mdm} 2$. Oncogene 16: 3317-3322

26. Honda $R$, Tanaka $H$ and Yasuda $H$ (1997) Oncoprotein MDM2 is a ubiquitin ligase E3 for tumor suppressor p53. FEBS Lett. 420: 25-27 
27. Honda R and Yasuda $H$ (1999) Association of $p 19^{A R F}$ with Mdm2 inhibits ubiquitin ligase activity of Mdm2 for tumor suppressor p53. EMBO J. 18:22-27

28. Fang S, Jensen JP, Ludwig RL, Vousden KH and Weissman AM (1999) Ubiquitin protein ligase activity of $\mathrm{mdm} 2$ : Differential RING finger requirements for ubiquitination and proteasomal targeting of mdm2 and p53. Unpublished

29. Hershko A and Ciechanover A (1998) The ubiquitin system. Annu. Rev. Biochem. 67: 425-479

30. Lorick KL, Jensen JP, Fang S, Ong AM, Hatakeyama S and Weissman AM (1999) RING fingers mediate ubiquitin-conjugating enzyme (E2)-dependent ubiquitination. Proc. Natl. Acad. Sci. USA 96: 11364-11369

31. Roth J, Dobbelstein M, Freedman DA, Shenk T and Levine AJ (1998) Nucleocytoplasmic shuttling of the hdm2 oncoprotein regulates the levels of the p53 protein via a pathway used by the human immunodeficiency virus rev protein. EMBO J. 17: 554-564

32. Freedman DA and Levine AJ (1998) Nuclear export is required for degradation of endogenous p53 by MDM2 and human papillomavirus E6. Mol. Cell. Biol. 18 : $7288-7293$

33. Lain S, Midgley C, Sparks A, Lane EB and Lane DP (1999) An inhibitor of nuclear export activates the p53 response and induces the localization of HDM2 and p53 to U1A-positive nuclear bodies associated with the PODS. Exp. Cell. Res. 248: $457-472$

34. Tao W and Levine AJ (1999) Nucleocytoplasmic shuttling of oncoprotein Hdm2 is required for Hdm2-mediated degradation of p53. Proc. Natl. Acad. Sci. USA 96: $3077-3080$

35. Tao W and Levine AJ (1999) p19ARF stabilizes p53 by blocking nucleocytoplasmic shuttling of Mdm2. Proc. Natl. Acad. Sci. U.S.A. 96: 6937-6941

36. Stommel JM, Marchenko ND, Jimenez GS, Moll UM, Hope TJ and Wahl GM (1999) A leucine-rich nuclear export signal in the p53 tetramerization domain: regulation of subcellular localization and $\mathrm{p} 53$ activity by NES masking. EMBOJ. 18: $1660-1672$

37. Avantaggiati ML, Ogryzko V, Gardner K, Giordano A, Levine AS and Kelly K (1997) Recruitment of p300/CBP in p53-dependent signal pathways. Cell 89: $1175-1184$

38. Gu W, Shi X-L and Roeder RG (1997) Synergistic activation of transcription by CBP and p53. Nature 387: 819-823

39. Lill NL, Grossman SR, Ginsberg D, DeCaprio J and Livingston DM (1997) Binding and modulation of p53 by p300/CBP coactivators. Nature 387: $823-$ 827

40. Scolnick DM, Chehab NH, Stavridi ES, Lien MC, Caruso L, Moran E, Berger SL and Halazonetis TD (1997) CREB-binding protein and p300/CBP-associated factor are transcriptional coactivators of the p53 tumor suppressor protein. Cancer Res. 57: 3693-3696

41. Thomas $A$ and White $E$ (1998) Suppression of the p300-dependent $m d m 2$ negative-feedback loop induced the p53 apoptotic function. Genes and Dev. 12: $1975-1985$

42. Grossman SR, Perez M, Kung AL, Joseph M, Mansur C, Xiao ZX, Kumar S, Howley PM and Livingston DM (1998) p300/MDM2 complexes participate in MDM2-mediated p53 degradation. Mol. Cell. 2: 405-415

43. Jost CA, Marin MC and Kaelin Jr WG (1997) p73 is a human p53-related protein that can induce apoptosis. Nature 389: 191-194

44. Zhu J, Jiang J, Zhou W and Chen X (1998) The potential tumor suppressor p73 differentially regulates cellular p53 target genes. Cancer Res. 58: 5061-5065

45. Di Como CJ, Gaiddon C and Prives C (1999) p73 function is inhibited by tumorderived p53 mutants in mammalian cells. Mol. Cell. Biol. 19: 1438-1449

46. Lee C-W and La Thangue NB (1999) Promotor specificity and stability control of the p53-related protein p73. Oncogene 18: 4171-4181

47. Zeng X, Chen L, Jost CA, Maya R, KellerD, Wang X, Kaelin WGJ, Oren M, Chen $\mathrm{J}$ and Lu H (1999) MDM2 suppresses p73 function without promoting p73 degradation. Mol. Cell. Biol. 19: 3257-3266

48. Balint $\mathrm{E}$ and Vousden $\mathrm{KH}$ (1999) Mdm2 binds $\mathrm{p73} \alpha$ without targeting degradation. Oncogene 18: 3923-3929

49. Dobbelstein M, Wienzek S, Koenig S and Roth J (1999) Inactivation of the p53homologue p73 by the mdm2-oncoprotein. Oncogene 18: 2101-2106

50. Ongkeko WM, Wang XQ, Siu WY, Lau AWS, Yamashita K, Harris AL, Cox LS and Poon RYC (1999) MDM2 and MDMX bind and stabilize the p53-related protein p73. Current Biology 9: 829-832

51. Kubbutat MHG, Ludwig RL, Ashcroft M and Vousden KH (1998) Regulation of Mdm2 directed degradation by the C-terminus of p53. Mol. Cell. Biol. 18:56905698
52. Meek DW (1998) Multisite phosphorylation and the integration of stress signals at p53. Cell Signal. 10: 159-166

53. Jayaraman $L$ and Prives $C$ (1999) Covalent and noncovalent modifiers of the p53 protein. Cell. Mol. Life Sci. 55: 76-87

54. Shieh S-Y, Ikeda M, Taya $Y$ and Prives C (1997) DNA damage-induced phosphorylation of p53 alleviates inhibition by MDM2. Cell 91: 325-334

55. Unger T, Juven-Gershon T, Moallem E, Berger M, Vogt Sionov R, Lozano G, Oren M and Haupt $Y$ (1999) Critical role for Ser20 of human p53 in the negative regulation of $p 53$ by Mdm2. EMBO J. 18: 1805-1814

56. Fuchs SY, Adler V, Pincus MR and Ronai Z (1998) MEKK1/JNK signaling stabilizes and activates p53. Proc. Natl. Acad. Sci. USA 95: 10541-10546

57. Böttger V, Böttger A, Garcia-Echeverria C, Ramos YF, van der Eb AJ, Jochemsen AG and Lane DP (1999) Comparative study of the p53-mdm2 and p53-MDMX interfaces. Oncogene 18: 189-199

58. Kussie PH, Gorina S, Marechal V, Elenbaas B, Moreau J, Levine AJ and Pavletich NP (1996) Structure of the MDM2 oncoprotein bound to the p53 tumor suppressor transactivation domain. Science 274: 948-953

59. Ashcroft M, Kubbutat MH and Vousden KH (1999) Regulation of p53 function and stability by phosphorylation. Mol. Cell. Biol. 19: 1751-1758

60. Blattner C, Tobiasch E, Litfen M, Rahmsdorf HJ and Herrlich P (1999) DNA damage induced p53 stabilization: no indication for an involvement of p53 phosphorylation. Oncogene 18: 1723-1732

61. Ashcroft M and Vousden KH (1999) Regulation of p53 stability. Oncogene In press

62. Barak Y and Oren M (1992) Enhanced binding of a $95 \mathrm{kDa}$ protein to $\mathrm{p} 53$ in cells undergoing p53-mediated growth arrest. EMBO J. 11: 2115-2121

63. Mayo LD, Turchi JJ and Berberich SJ (1997) Mdm-2 phosphorylation by DNAdependent protein kinase prevents interaction with p53. Cancer Res. 57: 5013-5016

64. Guerra B, Gotz C, Wagner P, Montenarh M and Issinger OG (1997) The carboxy terminus of p53 mimics the polylysine effect of protein kinase CK2-catalyzed MDM2 phosphorylation. Oncogene 14: 2683-2688

65. Serrano M, Hannon GJ and Beach D (1993) A new regulatory motif in cell-cycle control causing specific inhibition of cyclin D/CDK4. Nature 366: 704-707

66. Kamb A, Gruis NA, Weaver-Feldhaus J, Liu Q, Harshman K, Tavtigian SV, StockertE, Day IIIRS, Johnson BE and SkolnickMH(1994)A cell cycle regulator potentially involved in genesis of many tumor types. Science 264: 436-440

67. Nobori T, Miura K, Wu DJ, Lois A, Takabayashi K and Carson DA (1994) Deletions of the cyclin-dependent kinase- 4 inhibitor gene in multiple human cancers. Nature 368: 753-756

68. Mao L, Merlo A, Bedi G, Shapiro GI, Edwards CD, Rollins BJ and Sidransky D (1995) A novel p16INK4A transcript. Cancer Res. 55: 2995-2997

69. Duro D, Bernard O, Della Valle V, Berger R and Larsen C-J (1995) A new type of p16/INK4a/MTS1 gene transcript expressed in B-cell malignancies. Oncogene 11: $21-29$

70. Quelle DE, ZindyF, AshmunRA and SherrCJ(1995) Alternative reading frames of the INK4a tumor suppressor gene encode two unrelated proteins capapble of inducing cell cycle arrest. Cell 83: 993-1000

71. Foulkes WD, Flanders TY, Pollock PM and Hayward NK (1997) The CDK2A (p16) gene and human cancer. Mol. Med. 3: 5-20

72. Ruas M and Peters $G$ (1998) The p16INK4a tumor suppressor and its relatives. Biochim. Biophys. Acta 1378: F115-F177

73. Kamijo T, Zindy F, Roussel MF, Quelle DE, Downing JR, Ashmun RA, Grosveld $G$ and Sherr CJ (1997) Tumor suppression at the mouse INK4a locus mediated by the alternative reading frame product $p 19^{A R F}$. Cell 91: 649-659

74. Stott F, Bates SA, James M, McConnell BB, Starborg M, Brookes S, Palmero I, Hara E, Ryan KM, Vousden KH and Peters G (1998) The alternative product from the human $C D K N 2 A$ locus, $\mathrm{p} 14^{\mathrm{ARF}}$, participates in a regulatory feedback loop with p53 and MDM2. EMBO J. 17: 5001-5014

75. Kamijo T, Weber JD, Zambetti G, Zindy F, Roussel MF and Sherr CJ (1998) Functional and physical interactions of the ARF tumor suppressor with p53 and Mdm2. Proc. Natl. Acad. Sci. USA 95: 8292-8297

76. Pomerantz J, Schreiber-Agus N, Liégeois NJ, Silverman A, Alland L, Chin L, Potes J, Chen K, Orlow I, Lee H-W, Cordon-Cardo C and DePinho RA (1998) The Ink4a tumor suppressor gene product, p19 ${ }^{\text {Arf }}$, interacts with MDM2 and neutralizes MDM2's inhibition of $p 53$. Cell 92: 713-723

77. Zhang Y, Xiong Y and Yarbrough WG (1998) ARF promotes MDM2 degradation and stabilizes p53: ARF-INK4a locus deletion impairs both the $\mathrm{Rb}$ and p53 tumor suppression pathways. Cell 92: 725-734 
78. Zhang $Y$ and Xiong $Y$ (1999) Mutations in human ARF exon 2 disrupt its nucleolar localization and impair its ability to block nuclear export of Mdm2 and p53. Mol. Cell. 3: 579-591

79. Weber JD, Taylor LJ, Roussel MF, Sherr CJ and Bar-Sagi D (1999) Nucleolar Arf sequesters Mdm2 and activates p53. Nature Cell Biol. 1: 20-26

80. Hall M and Peters G (1996) Genetic alteraions of cyclins, cyclin dependent kinases and cdk inhibitors in human cancers. Adv. Cancer Res. 68: 67-108

81. Nevins JR (1998) Towards an understanding of the functional complexity of the E2F and retinoblastoma families. Cell Growth \& Diff. 9: 585-593

82. Bates S, Phillips AC, Clarke PA, Stott F, Peters G, Ludwig RL and Vousden KH (1998) p14 ${ }^{\mathrm{ARF}}$ links the tumour suppressors RB and p53. Nature 395: $124-$ 125

83. de Stanchina E, McCurrach ME, Zindy F, Shieh SY, Ferbeyre G, Samuelson AV, Prives C, Roussel MF, Sherr CJ and Lowe SW (1998) E1A signaling to p53 involves the p19(ARF) tumor suppressor. Genes Dev 12: 2434-2442

84. Palmero I, Pantoja C and Serrano M (1998) p19ARF links the tumour suppressor p53 to Ras. Nature 395: 125-126

85. Zindy F, Eischen CM, Randle DH, Kamijo T, Cleveland JL, Sherr CJ and Roussel MF (1998) Myc signaling via the ARF tumor suppressor regulates p53dependent apoptosis and immortalization. Genes Dev 12: 2424-2433

86. Radfar A, Unnikrishnan I, Lee HW, DePinho RA and Rosenberg N (1998) p19(Arf) induces p53-dependent apoptosis during abelson virus-mediated preB cell transformation. Proc. Natl. Acad. Sci. U.S.A. 95: 13194-13199

87. Hateboer G, Kerkhoven RM, Shvarts A, Bernards R and Beijersbergen RL (1996) Degradation of E2F by the ubiquitin-proteasome pathway: regulation by retinoblastoma family proteins and adenovirus transforming proteins. Genes Dev. 10: 2960-2970

88. Martin K, Trouche D, Hagemeier C, Sørensen TS, La Thangue NB and Kouzarides T (1995) Stimulation of E2F1/DP1 transcriptional activity by MDM2 oncoprotein. Nature 375: 691-694

89. Blattner C, Sparks A and Lane D (1999) Transcription factor E2F-1 is upregulated in response to DNA damage in a manner analogous to that of p53. Mol. Cell. Biol. 19: 3704-3713

90. Hickman ES, Bates S and Vousden KH (1997) Perturbation of the p53 response by human papillomavirus type 16 E7. J. Virol. 71: 3710-3718

91. Seavey SE, Holubar M, Saucedo LJ and Perry ME (1999) The E7 oncoprotein of human papillomavirus type 16 stabilizes p53 through a mechanism independent of p19ARF. J. Virol. 73: 7590-7598

92. Phillips AC, Bates S, Ryan KM, Helin K and Vousden KH (1997) Induction of DNA synthesis and apoptosis are separable functions of E2F-1. Genes and Dev. 11: $1853-1863$

93. Hsieh J-K, Fredersdorf S, Kouzarides T, Martin K and Lu X (1997) E2F-1induced apoptosis requires DNA binding but not transactivation and is inhibited by the retinoblastoma protein through direct interaction. Genes and Dev. 11: $1840-1852$

94. Phillips AC, Ernst MK, Bates S, Rice NR and Vousden KH (1999) E2F-1 potentiates cell death by blocking anti-apoptotic signaling pathways. Mol. Cell. 4: $771-781$

95. Kaelin WGJ (1999) The emerging p53 gene family. J. Natl. Cancer Inst. 91: $594-598$

96. Yang A, Kaghad M, Wang Y, Gillett E, Fleming MD, Dötsch V, Andrews NC Caput D and McKeon F. (1998). p63, a p53 homolog at 3q27-29 encodes multiple products with transactivation death-inducing and dominant-negative activites. Mol Cell 2: 305-316.

97. Sionov RV, Moallem E, Berger M, Kazaz A, Gerlitz O, Ben-Neriah Y, Oren M and Haupt $Y$ (1999) C-Abl neutralizes the inhibitory effect of Mdm2 on p53. J. Biol. Chem. 274: 8371-8374
98. Hsieh JK, Chan FS, O'Connor DJ, Mittnacht S, Zhong S and Lu X (1999) RB regulates the stability and the apoptotic function of p53 via MDM2. Mol. Cell 3: $181-193$

99. Damalas A, Ben-Ze'ev A, Simcha I, Shtutman M, Fernando J, Leal M, Zhurinsky J, Geiger B and Oren M (1999) Excess $\beta$-catenin promotes accumulation of transcriptionally active $\mathrm{p53}$. EMBO J. 18: $3054-3063$

100. Moll UM, LaQuaglia M, Benard J and Riou G (1995) Wild-type p53 protein undergoes cytoplasmic sequestration in undifferentiated neuroblastomas but not in differentiated tumors. Proc. Natl. Acad. Sci. USA 92: 4407-4411

101. Zaika A, Marchenko N and Moll UM (1999) Cytoplasmically "sequestered" wild type 53 protein is resistant to Mdm2-mediated degradation. J. Biol. Chem. 274 : $27474-27480$

102. Arriola EL, Rodriguez Lopez A and Chresta CM (1999) Differential regulation of p2 $1^{\text {waf- } 1 / \text { cip-1 }}$ and Mdm2 by etoposide: etoposide inhibits the p53-Mdm2 autoregulatory loop. Oncogene 18: 1081-1091

103. Wu L and Levine AJ (1997) Differential Regulation of the p21/WAF-1 and $m d m 2$ genes after high dose UV irradiation: p53-dependent and p53-independent regulation of the $m d m 2$ gene. Mol. Med. 3: $441-451$

104. Fuchs SY, Dolan L, Davis RJ and Ronai Z (1996) Phosphorylation-dependent targeting of c-Jun ubiquitination by Jun N-kinase. Oncogene 8: 1531-1535

105. Fuchs SY, Xie B, Adler V, Fried VA, Davis RJ and Ronai Z (1997) c-Jun NH2terminal kinases target the ubiquitination of their associated transcription factors. J. Biol. Chem. 272: 32163-32168

106. Fuchs SY, Adler V, Buschmann T, Yin Z, Wu X, Jones SN and Ronai Z (1998) JNK targets p53 ubiquitination and degradation in nonstressed cells. Genes and Dev. 12: 2658-2663

107. Gong JG, Costanzo A, Yang H-Q, Melino G, Kaelin WG, Levrero M and Wang JYJ (1999) The tyrosine kinase c-Abl regulates p73 in apoptotic response to cisplation-induced DNA damage. Nature 399: 806-809

108. Agami R, Blandino G, Oren M and Shaul Y (1999) Interaction of c-Abl and p73alpha and their collaboration to induce apoptosis. Nature 399: 809-813

109. Yuan Z-M, Shioya H, Ishiko T, Sun X, Gu J, Huang YY, Lu H, Kharbanda S, Weichselbaum $R$ and Kufe $D$ (1999) p73 is regulated by tyrosine kinase c-Abl in the apoptotic response to DNA damage. Nature 399: 814-817

110. Baskaran R, Wood LD, Whitaker LL, Canman CE, Morgan SE, Xu Y, Barlow C, Baltimore D, Wynshow-Boris A, Kastan MB and Wang JY (1997) Ataxia telangiectasia mutant protein activates $c$-Abl tyrosine kinase in response to ionizing radiation. Nature 387: $516-519$

111. Shafman T, Khanna KK, KedarP, Spring K, Kozlov S, Yen T, HobsonK, GateiM, Zhang N, Watters D, Egerton M, Shiloh Y, Kharbanda S, Kufe D and Lavin M (1997) Interaction between ATM protein and c-Abl in response to DNA damage. Nature 387: $520-523$

112. Yuan Z-M, Huang Y, Whang Y, Sawyers $C$, Weichselbaum R, Kharbanda S and Kufe D (1996) Role for c-Abl tyrosine kinase in growth arrest response to DNA damage. Nature 382: 272-274

113. White $E$ and Prives $C$ (1999) DNA damage enables p73. Nature 399: 734-737

114. Yang A, Schweitzer R, Sun D, Kaghad M, Walker N, Bronson RT, Tabin C, Sharpe A, Caput D, Crum C and McKeon F (1999) p63 is essential for regenerative proliferation in limb, craniofacial and epithelial development. Nature 398: 714-717

115. Mills AA, Zheng B, Wang X-J, Vogel H, Roop DR and Bradley A (1999) p63 is a p53 homologue required for limb and epidermal morphogenesis. Nature 398 : $708-713$ 